Article

\title{
Reduced Herbicide Antagonism of Grass Weed Control through Spray Application Technique
}

\author{
Luke H. Merritt ${ }^{1,2}{ }^{*}$, Jason Connor Ferguson ${ }^{1}\left(\right.$, Ashli E. Brown-Johnson ${ }^{3}$, \\ Daniel B. Reynolds ${ }^{1}(\mathbb{D})$, Te-Ming Tseng ${ }^{1}(\mathbb{D})$ and John Wesley Lowe ${ }^{4}(\mathbb{D}$ \\ 1 Department of Plant and Soil Science, Mississippi State University, Starkville, MS 39762, USA; \\ connor.ferguson@msstate.edu (J.C.F.); dbr6@msstate.edu (D.B.R.); tt1024@msstate.edu (T.-M.T.) \\ 2 Department of Crop Sciences, University of Illinois, Urbana, IL 61801, USA \\ 3 Mississippi State Chemical Laboratory, Starkville, MS 39762, USA; abrown@mscl.msstate.edu \\ 4 Department of Agricultural and Biological Engineering, Mississippi State University, \\ Starkville, MS 39762, USA; wlowe@abe.msstate.edu \\ * Correspondence: lukem@illinois.edu; Tel.: +1-217-577-1358
}

Received: 16 July 2020; Accepted: 31 July 2020; Published: 4 August 2020

\begin{abstract}
Dicamba and 2,4-D tolerance traits were introduced to soybean and cotton, allowing for over the top applications of these herbicides. Avoiding antagonism of glyphosate and clethodim by dicamba or 2,4-D is necessary to achieve optimum weed control. Three field studies were conducted in fallow fields with broadleaf signalgrass (Urochloa platyphylla) and Italian ryegrass (Lolium perenne ssp. multiflorum) pressure. A tractor-mounted dual boom sprayer was modified to spray one of three application methods: (1) two herbicides tanked-mixed (TMX); (2) two herbicides in separate tanks mixed in the boom line (MIL); and (3) two herbicides in separate tanks applied through separate booms simultaneously (SPB). One study compared the three application methods with sethoxydim applied with bentazon, the second compared clethodim applied with dicamba or 2,4-D, and the third compared glyphosate applied with dicamba or 2,4-D. In most cases over all three trials, there was a $7-15 \%$ increase in efficacy when using the SPB application method. Antagonism of all the herbicide combinations above was observed when applied using the TMX and MIL methods. In some cases, antagonism was avoided when using the SPB method. The separate boom application method increased efficacy, which allowed herbicides to be used more effectively, resulting in improved economic and environmental sustainability of herbicide applications.
\end{abstract}

Keywords: application technology; grass control; Italian ryegrass; broadleaf signalgrass; tank-mixture; herbicide efficacy

\section{Introduction}

Tank-mixing herbicides is a logistical way to apply multiple modes-of-action in a single herbicide application. Colby [1] produced a mathematical equation to determine if herbicide combinations produce antagonistic or synergistic responses. Colby's equation for testing a two-herbicide combination is the following:

$$
\mathrm{E}=(\mathrm{X}+\mathrm{Y})-(\mathrm{XY}) / 100
$$

where $\mathrm{X}$ is percent control of herbicide $\mathrm{A}, \mathrm{Y}$ is percent control of herbicide $\mathrm{B}$, and $\mathrm{E}$ is the expected amount of control. This formula was transformed from percent inhibition values to percent of control [1,2]. Antagonism is when the result of two or more chemicals combined is less than the predicted effect of each herbicide applied separately, while synergism is when the response is greater than expected [1,3]. Even today, the Colby method is widely used to determine antagonistic and synergistic combinations. Many factors affect herbicide antagonism including herbicide rate. The rate 
of a herbicide used may affect antagonism and increasing the rate may overcome antagonism taking place $[4,5]$. Buffering agents can adjust the spray solution $\mathrm{pH}$ and prevent antagonistic ions from interacting if the antagonism is due to chemical antagonism [6]. Penner [7] found that adjuvants can reduce antagonism by increasing the absorption of the herbicide and prevent derivative forms of weak acid herbicides from forming and absorbed into plant tissues. Many factors can lead to herbicide antagonism such as the plant species that is being sprayed, herbicide safeners, other pesticides, growth stage, application method, and the environment [8].

The 2016 growing season was the first year that Bayer released Roundup Ready 2 Xtend ${ }^{\circledR}$ soybean (Glycine max) and cotton (Gossypium hirsutm) varieties [9]. This event is significant in the fact that dicamba (Weed Science Society of America (WSSA) and Herbicide Resistance Action Committee (HRAC) Group 4) could be applied in postemergence weed control in soybean and cotton production. The dicamba trait allows for a herbicide application of Roundup PowerMAX ${ }^{\circledR}$ (glyphosate-WSSA/HRAC Group 9) with XtendiMax ${ }^{\circledR}$ (dicamba). Corteva Agriscience released crops with 2,4-D (WSSA/HRAC Group 4) tolerance, known as Enlist ${ }^{\mathrm{TM}}$ soybeans, cotton, and corn [10]. Between the two trait tolerant systems, 2,4-D and dicamba may be used for postemergence applications in soybeans and cotton.

Herbicides used to control grasses, such as clethodim (WSSA/HRAC Group 1), in addition to the use of broadleaf control herbicides such as 2,4-D or dicamba in a postemergence application are necessary to achieve control of a broad spectrum of weeds. Zollinger [11] reported antagonism with dicamba and clethodim in grass control. Control of southern crabgrass (Digitaria ciliaris) with clethodim applied $24 \mathrm{~h}$ before a broadleaf herbicide showed little to no antagonism while the tank-mixes of the same herbicides were antagonistic [12]. Although tank-mixing herbicides is an effortless way to apply multiple herbicides at one time, applying the herbicides separately may prevent antagonism from occurring. When clethodim was applied alone, Grichar et al. [12] saw 95\% control in 1996 and less than $80 \%$ control in 1997 and 1999 of southern crabgrass. When clethodim was followed by acifluorfen (WSSA/HRAC Group 14) plus bentazon (WSSA/HRAC Group 6) or 2,4-D, the control of southern crabgrass dropped to below $50 \%$. The extra $24 \mathrm{~h}$ allowed the herbicide to start working within the plant before a second herbicide could interfere with it. In the same studies by Grichar et al. [12], clethodim had lower control of broadleaf signalgrass (Urochloa platyphylla) when it was tanked-mixed with each of the broadleaf herbicides in the study. Grichar et al. [12] concluded that less antagonism occurred when clethodim was applied $24 \mathrm{~h}$ before or after a broadleaf herbicide application. Underwood et al. [13] also saw an antagonistic response of volunteer corn control when clethodim was tank-mixed with dicamba.

Antagonism can take place when glyphosate is tank-mixed with dicamba or 2,4-D [14]. With consumers showing concern for health and environmental effects from herbicide use, increasing use rates of herbicides to make up for antagonism may bring more concerns from consumers to the agriculture industry [15-17]. Antagonism of sethoxydim (WSSA/HRAC Group 1) applied with bentazon is well documented in the literature. Tank mixing sethoxydim with bentazon reduces sethoxydim activity on grass weed species in the field [18-22]. Sequential applications of sethoxydim and bentazon have shown in some cases to prevent antagonism [22]. Increasing the sethoxydim rate reduced the severity of the antagonism [22]. Rhodes Jr. and Coble [23] found that the application of bentazon with sethoxydim decreased foliar adsorption of 14C applied as 14C-sethoxydim by $50 \%$ in goosegrass (Eleusine indica). Carrier volume can influence the efficacy of sethoxydim. Lassiter and Coble [24] found that a carrier volume of 94 and $187 \mathrm{~L} \mathrm{ha}^{-1}$ had better large crabgrass control than $374 \mathrm{~L} \mathrm{ha}^{-1}$ for sethoxydim applied alone and sethoxydim and bentazon sequential application. There was no carrier volume effect for the sethoxydim and bentazon tank mix treatment [24]. Zhang et al. reviewed antagonism and synergism studies [5]. Thirty-three percent of 267 studies had synergistic combinations and $67 \%$ had antagonistic combinations. Acetyl Co-A Carboxylase (ACCase) inhibiting herbicides (WSSA/HRAC Group 1), tanked mixed with synthetic auxins (WSSA/HRAC Group 4) was a common antagonistic herbicide mix. 
New dicamba and 2,4-D trait technologies in cotton and soybeans means that the antagonistic response with tank-mixes of common grass herbicides with 2,4-D and dicamba is a renewed concern. Synthetic auxins provide excellent broadleaf weed control, but ACCase herbicides must be added to control grass weeds. Controlling both grass and broadleaf weeds will be more difficult with antagonism occurring. Even though tank-mixing herbicides is an effortless way to apply multiple herbicides at one time, applying the herbicides separately may prevent the occurrence of antagonism. The objective of this study was to examine if delaying herbicide interaction time with the different application methods reduced or overcame antagonism occurring in weedy grass species. Three field studies were conducted to observe differences in grass control with known herbicide antagonistic combinations. The results from these three studies will show if delaying the time that different herbicides interact effect herbicide efficacy. While some herbicides have rate and adjuvant recommendations when used in applications of row crops, it is important to know if a change in herbicide application method may alter the recommendations and common standards in place.

\section{Materials and Methods}

Field studies took place in three site-years at the Black Belt Experiment Station in Brooksville, Mississippi, USA and at the R.R. Foil Plant Science Research Center in Starkville, Mississippi, USA in the 2018 and 2019 growing seasons. For all three site-years, a modified tractor (John Deere 5400 series) mounted dual boom research sprayer was used to make one of the three application methods: (1) the two herbicides tanked mixed in a can and sprayed through a single boom (Figure 1); (2) two herbicides from separate cans mixed in the boom line and applied through a single boom (Figure 2); and (3) two herbicides from separate cans applied through both booms at the same time (Figure 3). Two of the three application methods delayed herbicide interaction time of herbicides from interacting in the tank (tank-mixture application). The mix-in-line method delayed herbicide interaction until they mixed in the boom line. The separate boom application method delayed herbicide interaction until they mixed in the air or on a plant's surface.

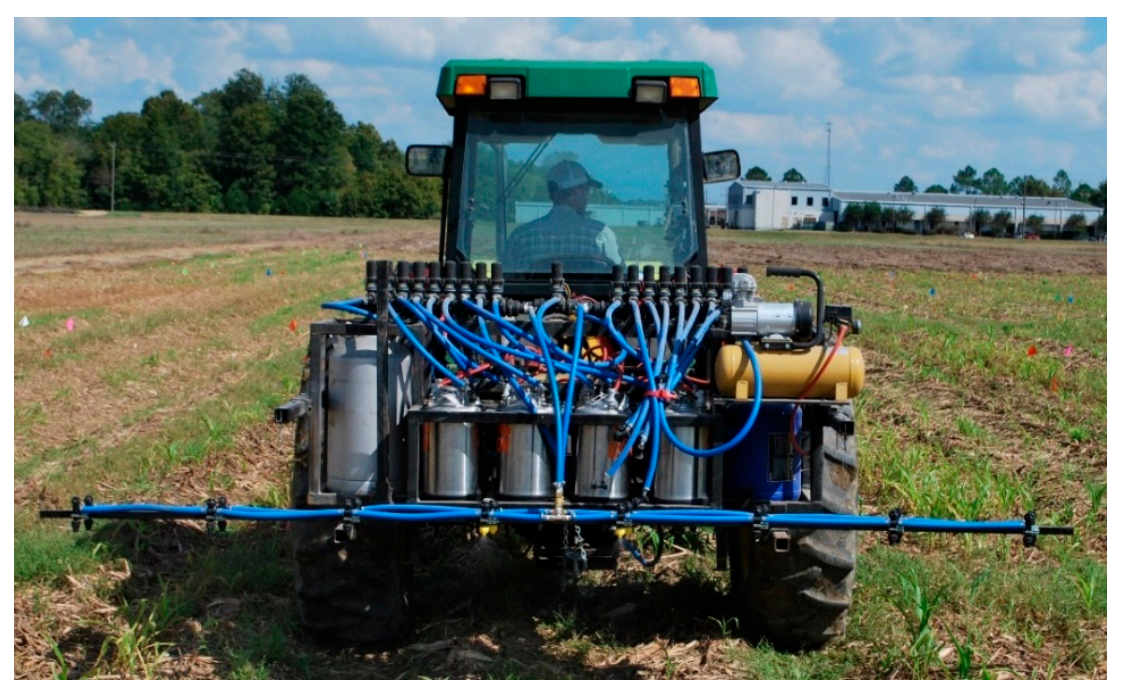

Figure 1. A tractor (John Deere 5400 series) mounted three-point hitch dual boom sprayer was modified to make three different herbicide applications. The cans containing herbicides were pressurized through a mounted air compressor. Two sets of eight 430 series, Two-way manifold (TeeJet Technologies, Glendale Heights, Illinois 60139, USA) were mounted to the sprayer with two separate control boxes in the cab of the tractor. Tank-mixture applications were mixed together in a can and applied through one, Teejet 430 series manifold. 


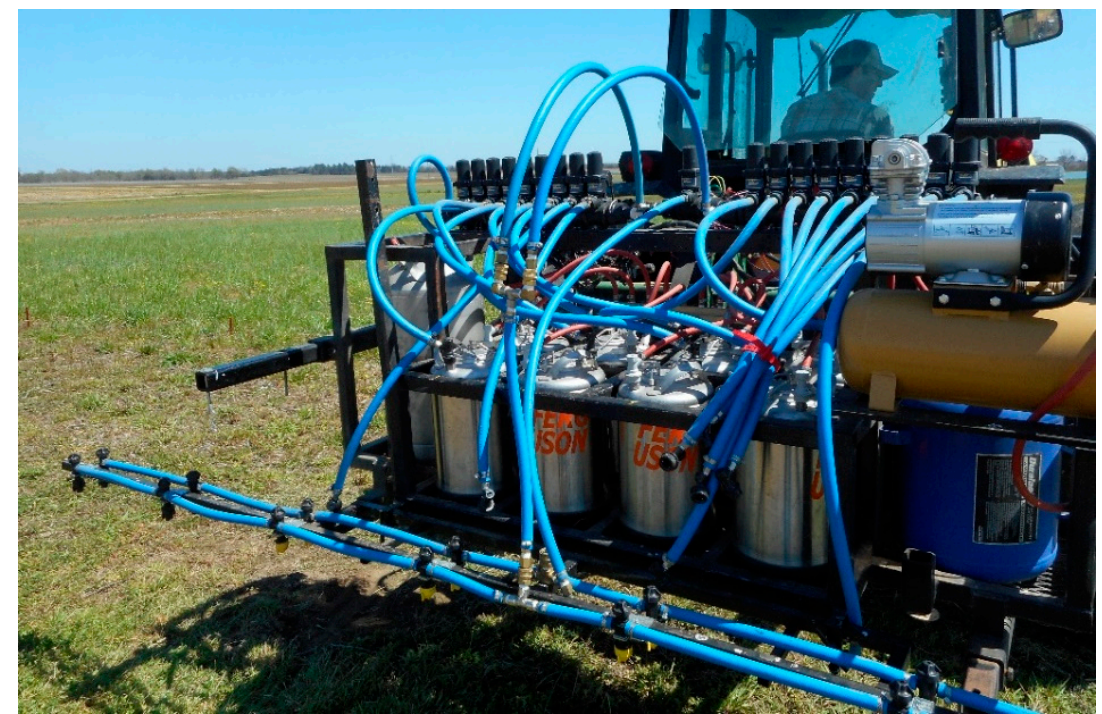

Figure 2. Mix-in-line applications were made from two separate cans, connected to separate manifolds. The two lines coming out of the manifolds were connected to a " $\mathrm{T}$ " that would allow the herbicides to mix before coming out of the nozzles. This " $\mathrm{T}$ " was only used in the mix-in-line applications and was removed for the other application types.

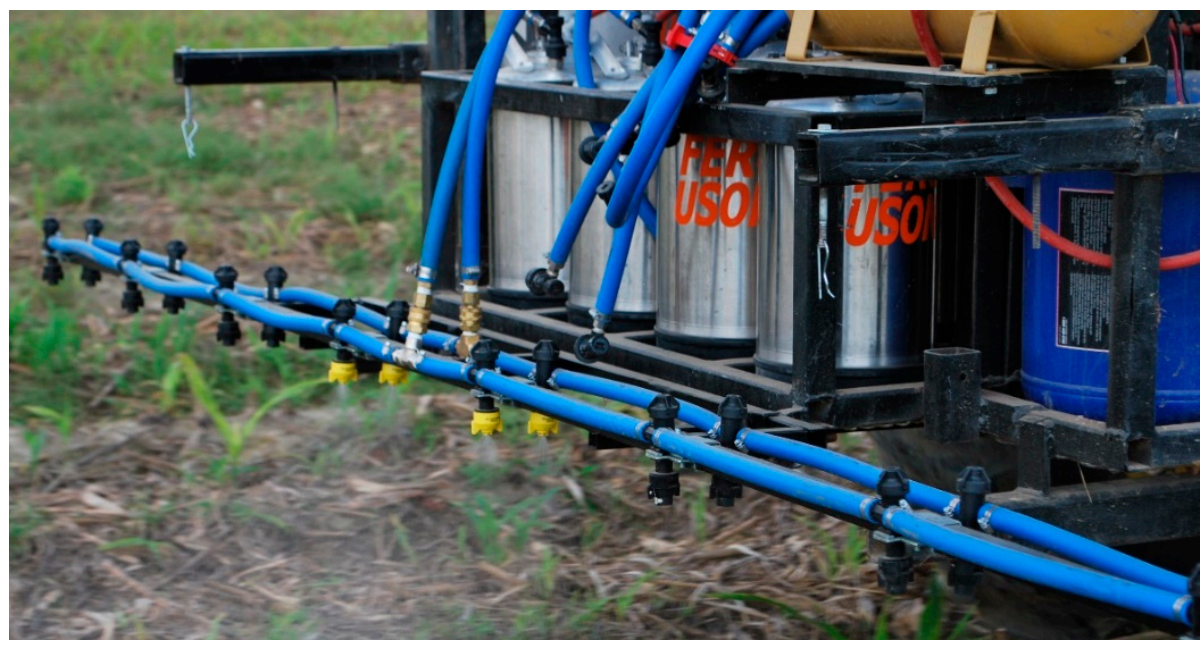

Figure 3. Separate nozzle applications were made from two cans containing separate herbicides and applied through separate manifolds. One manifold controlled one boom while the second manifold controlled the other boom. One button on each control box in the tractor were pressed to activate both cans spraying at the same time through both booms.

Each herbicide combination was applied using one of the three different application methods. In each trial, the herbicides used in the herbicide combinations were also individually applied to observe control from just the single herbicide. Recording results of the herbicides applied alone allowed the use of the Colby method to calculate expected herbicide response and determine if herbicide combinations were antagonistic.

All studies consisted of an untreated control with four replications in a randomized complete block design. Each block had an untreated control plot randomized with the treatments. All plots were $2.9 \mathrm{~m}$ wide by $9.1 \mathrm{~m}$ long. An untreated control was used for weed control evaluations. Control ratings were used taking the number of weeds in the untreated control and comparing each individual grass weed controlled in each treatment. Ratings were taken on a scale of $0-100 \%$ where $0 \%$ meant no control and $100 \%$ meant the plots were clean of the weeds rated. Populations of Italian ryegrass (Lolium perenne 
ssp. multiflorum) used, including the natural population at the Black Belt Experiment Station, were not glyphosate resistant.

\subsection{Sethoxydim and Bentazon Field Trial}

Two field study replications were conducted at the Black Belt Experiment Station in Brooksville, MS, USA and at the R.R. Foil Plant Science Research Center in Starkville, MS, USA on 29 March 2019 and 20 May 2019, respectively. The study consisted of an untreated control plus five treatments. All treatments with bentazon (Broadloom ${ }^{\mathrm{TM}}$, UPL, King of Prussia, PA, USA) and sethoxydim (Poast ${ }^{\circledR}$, BASF, Research Triangle Park, NC, USA) were applied at the rate of 840 and at $140 \mathrm{~g}$ ai ha ${ }^{-1}$, respectively, with crop oil concentrate (COC) (AGRI-DEX ${ }^{\circledR}$, Helena Agri-Enterprises LLC, Collierville, TN, USA) at $1 \% v / v$. The treatments were: (1) bentazon; (2) sethoxydim; (3) bentazon tanked-mixed with sethoxydim; (4) bentazon and sethoxydim applied through the mix-in-line method; and (5) bentazon and sethoxydim applied at the same time through different booms. The modified tractor mounted sprayer described in the Materials and Methods Section was used to make all herbicide applications.

An ammonia and water rinse of the system was conducted between each treatment change. This was done to ensure that the complete sprayer system was clean between each different herbicide applied. Applications were made at $276 \mathrm{kPa}$, with an application volume of $140 \mathrm{~L} \mathrm{ha}^{-1}$, at $6.7 \mathrm{~km} \mathrm{~h}^{-1}$. Nozzles used the study were Hypro Ultra Lo-Drift 120-02 s (ULD, Pentair-Hypro, New Brighton, MN 55112, USA). Applications were applied over a natural population of Italian ryegrass at an average height of $18 \mathrm{~cm}$, and BBCH Stages 33-38 at the first location at the Black Belt Experiment Station. The second location at the R.R. Foil Plant Science Research Center had had Oregon Grown, Gulf Variety, Italian ryegrass drilled into the field at a rate of $112 \mathrm{~kg} \mathrm{ha}^{-1}$ on 20 March 2019 along with a natural population of broadleaf signalgrass (Urochloa platyphylla). Applications were applied when Italian ryegrass and broadleaf signalgrass were at an average height of 15 and $9 \mathrm{~cm}$, respectively. Ryegrass plants were BBCH Stages 26-34 and broadleaf signalgrass plants were BBCH Stages 22-24. Visual estimation of injury (control) ratings were taken at 7, 14, 21, and 28 days after application (DAA).

\subsection{Clethodim with Synthetic Auxins Field Trial}

This trial had three site-years: fall 2018 at the R.R. Foil Plant Science Research Center (R.R. Foil) in Starkville, MS on 6 October 2018; the Black Belt Experiment Station (Black Belt) in Brooksville, MS on 29 March 2019; and again at the R.R. Foil Plant Science Research Center on 20 May 2019. The trial consisted of 17 treatments plus an untreated control. The tractor mounted sprayer described in the Materials and Methods Section was used to make herbicide applications using the three application methods. At the R.R. Foil Plant Science Research Center (Site-Year 1), all treatments with dicamba and 2,4-D were applied at 281 and $533 \mathrm{~g}$ ae $\mathrm{ha}^{-1}$, respectively. At the Black Belt Experiment Station (Site-Year 2) and at the R.R. Foil Plant Science Research Center (Site-Year 3), the dicamba and 2,4-D applications were increased to 562 and $1065 \mathrm{~g}$ ae ha ${ }^{-1}$, respectively. Herbicide rates were increased because of the result variability observed in Site-Year 1 . The salt formulations tested in all three locations were bis-aminopropyl methylamine (BAPMA) salt of dicamba (Engenia ${ }^{\circledR}$, BASF, Research Triangle Park, NC, USA), diglycolamine (DGA) salt of dicamba with vapor grip (FeXapan ${ }^{\circledR}$, Corteva Agriscience, Indianapolis, IN, USA), choline salt of 2,4-D (Enlist One ${ }^{\circledR}$, Corteva Agriscience), and dimethylamine (DMA) salt of 2,4-D Amine (Weed Rhap ${ }^{\circledR}$ A-4D, Helena Agri-Enterprises LLC, Collierville, TN, USA). All treatments with clethodim (Select Max ${ }^{\circledR}$, Valent, Walnut Creek, CA, USA) were made at a rate of $68 \mathrm{~g}$ ai ha ${ }^{-1}$ with a nonionic surfactant (NIS) (Activate Plus ${ }^{\mathrm{TM}}$, Winfield United, River Falls, WI 54022, USA) at $0.25 \% v / v$ for all three trial replications. Table 1 displays all the treatment combinations used in the three locations. 
Table 1. Complete Treatment Combination List for the Clethodim with Synthetic Auxins Field Study.

\begin{tabular}{|c|c|c|}
\hline Treatment & Application Method & Herbicide Active Ingredients(s) \\
\hline 1 & single application & BAPMA salt of dicamba \\
\hline 2 & single application & DGA salt of dicamba with vapor grip \\
\hline 3 & single application & choline salt of $2,4-\mathrm{D}$ \\
\hline 4 & single application & DMA salt of 2,4-D Amine \\
\hline 5 & single application & clethodim with NIS \\
\hline 6 & tank mix & BAPMA salt of dicamba and clethodim with NIS \\
\hline 7 & mix-in-line & BAPMA salt of dicamba and clethodim with NIS \\
\hline 8 & separate boom & BAPMA salt of dicamba and clethodim with NIS \\
\hline 9 & tank mix & DGA salt of dicamba with vapor grip and clethodim with NIS \\
\hline 10 & mix-in-line & DGA salt of dicamba with vapor grip and clethodim with NIS \\
\hline 11 & separate boom & DGA salt of dicamba with vapor grip and clethodim with NIS \\
\hline 12 & tank mix & choline salt of 2,4-D and clethodim with NIS \\
\hline 13 & mix-in-line & choline salt of 2,4-D and clethodim with NIS \\
\hline 14 & separate boom & choline salt of 2,4-D and clethodim with NIS \\
\hline 15 & tank mix & DMA salt of 2,4-D Amine and clethodim with NIS \\
\hline 16 & mix-in-line & DMA salt of 2,4-D Amine and clethodim with NIS \\
\hline 17 & separate boom & DMA salt of 2,4-D Amine and clethodim with NIS \\
\hline
\end{tabular}

All applications were made at $276 \mathrm{kPa}$, with an application volume of $140 \mathrm{~L} \mathrm{ha}^{-1}$ at $6.7 \mathrm{~km} \mathrm{~h}^{-1}$. In the 2018 fall study, the applications of the separate booms were applied at $70 \mathrm{~L} \mathrm{ha}^{-1}, 13.4 \mathrm{~km} \mathrm{~h}^{-1}$, and $276 \mathrm{kPa}$. This was done to achieve the same GPA application volume of $140 \mathrm{~L} \mathrm{ha}^{-1}$ because two sets of nozzles were being used. This method was then reverted to an application volume of $140 \mathrm{~L} \mathrm{ha}^{-1}$ with a speed of $6.7 \mathrm{~km} \mathrm{~h}^{-1}$ due to carrier volume having effects on efficacy [25]. Nozzles used in the study were Hypro Ultra Lo-Drift 120-02s (ULD). The first site-year at the R.R. Foil Plant Science Research Center had a stand of volunteer corn (Zea mays) and a natural population of browntop millet (Urochloa ramosa) that were sprayed at an average height of 15 and $9 \mathrm{~cm}$, respectively. Volunteer corn were BBCH Stages 12-15 and the browntop millet were BBCH Stages 51-59. The second site-year replication at the Black Belt Experiment Station had a uniform natural population of Italian Ryegrass (Lolium perenne ssp. multiflorum), and applications were made when the Italian ryegrass was at an average height of $18 \mathrm{~cm}$. The third site-year at the R.R. Foil Plant Science Research Center had Oregon Grown, Gulf Variety, Italian ryegrass drilled into the field at a rate of $112 \mathrm{~kg} \mathrm{ha}^{-1}$ on 20 March 2019 along with a natural population of broadleaf signalgrass. Applications were applied when Italian ryegrass and broadleaf signalgrass were at an average height of 15 and $9 \mathrm{~cm}$, respectively. Ryegrass plants were BBCH Stages 26-34 and broadleaf signalgrass plants were BBCH Stages 22-24. Visual estimation of injury control ratings was taken at 7, 14, 21, and 28 days after application (DAA).

\subsection{Glyphosate with Synthetic Auxins Field Trial}

This trial was conducted in the fall of 2018 at the R.R. Foil Plant Science Research Center in Starkville, MS on 5 October 2018 (Site-Year 1), Black Belt Experiment Station in Brooksville, MS on 28 March 2019 (Site-Year 2), and again at the R.R. Foil Plant Science Research Center on 20 May 2019 (Site-Year 3). This trial consisted of 17 treatments plus an untreated control. The tractor-mounted sprayer described in the Materials and Methods Section was used to make herbicide applications using the three application methods. Each herbicide combination was applied with the three different application methods. For the first site-year at the R.R. Foil Plant Science Research Center, all treatments with dicamba and 2,4-D were applied at 281 and $533 \mathrm{~g}$ ae ha $^{-1}$, respectively. For the second site-year replication at the Black Belt Experiment Station and the third site-year replication at the R.R. Foil Plant Science Research Center, the dicamba and 2,4-D applications were increased to 562 and $1065 \mathrm{~g}$ ae ha ${ }^{-1}$, respectively. Herbicide rates were increased because of the variability of results observed in first site-year. Salt formulations tested in all three trial replications were bis-aminopropyl methylamine (BAPMA) salt of dicamba (Engenia ${ }^{\circledR}$, BASF, Research Triangle Park, NC, USA), diglycolamine (DGA) 
salt of dicamba with vapor grip (FeXapan ${ }^{\circledR}$, Corteva Agriscience, Indianapolis, IN, USA), choline salt of 2,4-D (Enlist One ${ }^{\circledR}$, Corteva Agriscience), and dimethylamine (DMA) salt of 2,4-D Amine (Weed Rhap ${ }^{\circledR}$ A-4D, Helena Agri-Enterprises LLC, Collierville, TN, USA). All treatments with glyphosate were applied at a rate of $434 \mathrm{~g}$ ae ha ${ }^{-1}$ using Roundup PowerMAX ${ }^{\circledR}$ (Bayer, St. Louis, MO, USA) for all three trial replications. Table 2 displays all the treatment combinations used in all three site-year replications.

Table 2. Complete Treatment Combination List for the Glyphosate with Synthetic Auxins Field Study.

\begin{tabular}{ccc}
\hline Treatment & Application Method & Herbicide Active Ingredient(s) \\
\hline 1 & single application & BAPMA salt of dicamba \\
2 & single application & DGA salt of dicamba with vapor grip \\
3 & single application & choline salt of 2,4-D \\
4 & single application & glyphosate \\
5 & single application & tank mix \\
6 & mix-in-line & BAPMA salt of dicamba and glyphosate \\
7 & separate boom & BAPMA salt of dicamba and glyphosate \\
8 & tank mix & BAPMA salt of dicamba and glyphosate \\
9 & mix-in-line & DGA salt of dicamba with vapor grip and glyphosate \\
10 & separate boom & DGA salt of dicamba with vapor grip and glyphosate \\
11 & tank mix & choline salt of 2,4-D and glyphosate \\
12 & mix-in-line & choline salt of 2,4-D and glyphosate \\
13 & separate boom & choline salt of 2,4-D and glyphosate \\
14 & tank mix & DMA salt of 2,4-D Amine and glyphosate \\
15 & mix-in-line & DMA salt of 2,4-D Amine and glyphosate \\
16 & separate boom & DMA salt of 2,4-D Amine and glyphosate \\
17 & &
\end{tabular}

All applications were made at $276 \mathrm{kPa}$, with an application volume of $140 \mathrm{~L} \mathrm{ha}^{-1}$ at $6.7 \mathrm{~km} \mathrm{~h}^{-1}$ with ULD 120-02 nozzles. Visual estimation of injury (control) ratings were taken 7, 14, 21, and 28 days after application (DAA).The first site-year replication at the R.R. Foil Plant Science Research Center had a natural stand of browntop millet (Urochloa ramosa) that was sprayed at an average height of $9 \mathrm{~cm}$. Volunteer corn were BBCH Stages 12-15 and the browntop millet were BBCH Stages 51-59. The second site-year replication at the Black Belt Experiment Station had a natural thick stand of Italian Ryegrass (Lolium perenne ssp. multiflorum), and applications were made when the Italian ryegrass was at an average height of $18 \mathrm{~cm}$ and BBCH Stages 33-38. The third site-year at the R.R. Foil Plant Science Research Center had had Oregon Grown, Gulf Variety, Italian ryegrass drilled into the field at a rate of $112 \mathrm{~kg} \mathrm{ha}^{-1}$ on 20 March 2019 along with a natural population of broadleaf signalgrass. Applications were made when Italian ryegrass and broadleaf signalgrass was at an average height of 15 and $9 \mathrm{~cm}$, respectively. Ryegrass plants were $\mathrm{BBCH}$ Stages $26-34$ and broadleaf signalgrass plants were $\mathrm{BBCH}$ Stages 22-24.

\subsection{Statistical Analyses}

All results were run through SAS 9.4 through PROC GLIMMIX SAS (Statistical Analysis Software, version 9.4, Cary, North Carolina, USA) with Sidak's adjustment and $p$ value $=0.05$ [26]. Each weed specie at each location was separated and ran through statistical analysis individually for all three trials. In the clethodim and glyphosate trials, no statistical differences were found between dicamba and 2,4-D formulations, therefore data were pooled across dicamba and 2,4-D to look specifically at application method differences. Each weed species within each trial was analyzed individually to separate and discuss results clearly between each site location. For all three trials, the values from the herbicides applied individually were used in the Colby Method to determine if herbicide combinations are antagonistic [1]. 


\section{Results and Discussion}

\subsection{Sethoxydim with Bentazon Field Trial}

Results of weed control taken 28 DAA are displayed in Table 3. Italian ryegrass control at the Black Belt and Experiment and at the R.R. Foil Plant Science Research Center was highest with sethoxydim applied alone (68\% and 93\%, respectively) and with sethoxydim applied with bentazon through SPB (61\% and 83\%, respectively; Table 3). At Black Belt, applying sethoxydim with bentazon with the MIL method and TMX resulted in 35\% and 43\% control, respectively (Table 3). At R.R. Foil, applying sethoxydim with bentazon with the MIL method and TMX both resulted in 43\% control of Italian ryegrass (Table 3). This was significantly lower than the $61 \%$ control at Black Belt and the $83 \%$ control of Italian ryegrass at R.R. Foil with the sethoxydim applied with bentazon through SPB treatment (Table 3). Applying sethoxydim with bentazon through SPB resulted in similar weed control as sethoxydim applied alone in control of broadleaf signalgrass. Control of broadleaf signalgrass through tank mixing sethoxydim with bentazon was significantly lower than applying sethoxydim with bentazon through separate booms.

Table 3. Comparison of Sethoxydim Applied Alone with all Three Application Methods of Sethoxydim with Bentazon 28 Days After Application at the Black Belt Experiment Station (Black Belt) and the R.R. Foil Plant Science Research Center (R.R. Foil).

\begin{tabular}{|c|c|c|c|c|c|c|c|}
\hline \multirow{3}{*}{ Herbicide Treatment ${ }^{1}$} & \multirow{3}{*}{$\begin{array}{l}\text { Application } \\
\text { Method }\end{array}$} & \multirow{2}{*}{\multicolumn{2}{|c|}{$\begin{array}{c}\text { Black Belt Site-Year } 1 \\
\text { Italian Ryegrass }\end{array}$}} & \multicolumn{4}{|c|}{ R.R. Foil Site-Year 2} \\
\hline & & & & \multicolumn{2}{|c|}{ Italian Ryegrass } & \multicolumn{2}{|c|}{ Broadleaf Signalgrass } \\
\hline & & Obs $^{2}$ & $\operatorname{Exp}^{3}$ & Obs & Exp & Obs & Exp \\
\hline sethoxydim alone & & $68^{a}$ & & $93^{\mathrm{a}}$ & & $78^{\mathrm{a}}$ & \\
\hline bentazon alone & & $0^{c}$ & & $0^{\mathrm{c}}$ & & $0^{\mathrm{d}}$ & \\
\hline sethoxydim with bentazon & $\operatorname{tank} \operatorname{mix}$ & $43^{b}$ & 68 & $43^{b}$ & 93 & $10^{c}$ & 78 \\
\hline sethoxydim with bentazon & separate boom & $61^{a}$ & 68 & $83^{a}$ & 93 & $50^{a, b}$ & 78 \\
\hline
\end{tabular}

Data were analyzed using Sidak's comparison method. LS-means with different letters within the same column indicate significance. ${ }^{1}$ Herbicide rates are detailed in Section 2.1. " "Obs" is an abbreviation of Observed control and ${ }^{3}$ "Exp" is an abbreviation of Expected control using Colby's equation: $E=(X+Y)-(X Y) / 100$; any response of sethoxydim with bentazon that was significantly lower than sethoxydim alone is considered antagonistic.

The control ratings taken 21 DAA (data not shown) showed differences among the application methods. For Italian ryegrass control at the Black Belt Experiment Station, sethoxydim applied with bentazon through SPB was the only application method that resulted in similar weed control as sethoxydim applied by itself, with control being $60 \%$ and 51\%, respectively. Applying sethoxydim with bentazon by the TMX and MIL methods resulted in 30\% control of Italian ryegrass, while sethoxydim by itself resulted in $60 \%$ control. This shows that applying sethoxydim with bentazon with the TMX and MIL methods had lower weed control that sethoxydim applied with bentazon through SPB. Sethoxydim applied with bentazon was antagonistic when the two herbicides were tank mixed or applied through MIL applications. Results of Italian ryegrass control at the R.R. Foil Plant Science Research Center were slightly different from the results at the Black Belt Experiment Station. Applying sethoxydim with bentazon through SPB and TMX were similar to sethoxydim alone despite the $27 \%$ difference in mean control of Italian ryegrass 21 DAA. Control of broadleaf signal grass was highest with sethoxydim applied alone (50\%). All three application methods with sethoxydim applied with bentazon had significantly lower weed control than sethoxydim applied alone.

Antagonism of sethoxydim observed when tank mixed with bentazon in the two site-years of this study coincides with findings from Minton et al. [27] and Rhodes, Jr. and Coble [22]. Minton et al. [27] observed an $18 \%$ reduction in barnyardgrass control when bentazon was tank mixed with sethoxydim, and Rhodes Jr. and Coble [22] observed a 5-10\% decrease in control of multiple grass species when sethoxydim was applied with bentazon. Reduced sethoxydim efficacy was observed when bentazon was added in applications to control Texas panicum (Panicum texanum) and southern crabgrass 
(Digitaria ciliaris) control in peanuts [28]. When mixed together, sethoxydim $\mathrm{H}^{+}$hydroxyl group and $\mathrm{Na}^{+}$ions from bentazon exchange to form a sodium salt of sethoxydim [29]. This sodium salt of sethoxydim is more polar, and therefore absorption of sethoxydim is inhibited. Delaying the timing of sethoxydim and bentazon mixing until touching the plant leaf may have allowed enough time for enough sethoxydim to enter the plant before chemically reacting to bentazon.

\subsection{Clethodim with Synthetic Auxins Field Trial}

No grass control was observed from any dicamba or 2,4-D application in all three site-year replications. Any weed control lower than clethodim applied alone is considered antagonistic. Data from the visual estimation of weed control ratings at 7, 21, and 28 DAA were pooled across herbicide combinations within each grass species due to no difference found among the herbicide combinations. Applying dicamba or 2,4-D with clethodim with the TMX and SPB methods resulted in $88 \%$ and $92 \%$ control of volunteer corn, which was similar to the $96 \%$ control from the clethodim alone treatment 28 DAA (Table 4). The MIL method resulted in $60 \%$ control of volunteer corn 28 DAA, which was lower control than the clethodim applied alone treatment (Table 4). The SPB and the TMX application methods resulted in $34 \%$ and $27 \%$ control of browntop millet 28 DAA, respectively, which was similar in control (Table 4). The SPB application method resulted in $62 \%$ control of Italian ryegrass 28 DAA at Black Belt (Table 4). This was the only application method that resulted in Italian ryegrass control similar to the $63 \%$ control from applying clethodim alone. The TMX and MIL methods had $48 \%$ and $37 \%$ control of Italian ryegrass 28 DAA at Black Belt, respectively. Both methods had lower control of Italian ryegrass at Black Belt than the SPB and clethodim alone treatments (Table 4). Italian ryegrass control 28 DAA at R.R. Foil was highest with clethodim alone and the SPB application method, which was $93 \%$ and $89 \%$ control, respectively (Table 4). The TMX and MIL methods resulted in $75 \%$ and $54 \%$ control of Italian ryegrass, respectively, 28 DAA at R.R. Foil. Similar to the Italian ryegrass control results from Black Belt, the TMX and MIL methods resulted in lower control. Applying clethodim with dicamba or 2,4-D through separate booms was the only application method that resulted in control of Italian ryegrass at the Black Belt Experiment Station and at the R.R. Foil Plant Science Research Center that was similar to applying clethodim alone (Table 4). Applying clethodim with dicamba or 2,4-D through TMX or the MIL application methods resulted in lower control of Italian ryegrass compared to the SPB application method, therefore showing an antagonistic reaction.

Table 4. Comparison of application methods for control of volunteer corn, browntop millet, Italian ryegrass, and broadleaf signalgrass with clethodim and dicamba or 2,4-D 28 days after application.

\begin{tabular}{|c|c|c|c|c|c|c|c|c|c|c|}
\hline \multirow{3}{*}{ Application Method ${ }^{1}$} & \multirow{2}{*}{\multicolumn{2}{|c|}{$\begin{array}{c}\text { R.R. Foil } \\
\text { Site-Year } 1 \\
\text { Volunteer Corn }\end{array}$}} & \multirow{2}{*}{\multicolumn{2}{|c|}{$\begin{array}{c}\text { Black Belt } \\
\text { Site-Year } 2 \\
\text { Browntop Millet }\end{array}$}} & \multicolumn{6}{|c|}{ R.R. Foil Site-Year 3} \\
\hline & & & & & \multicolumn{2}{|c|}{ Italian Ryegrass } & \multicolumn{2}{|c|}{ Italian Ryegrass } & \multicolumn{2}{|c|}{ Broadleaf Signalgrass } \\
\hline & Obs $^{2}$ & $\operatorname{Exp}^{3}$ & Obs & Exp & Obs & $\operatorname{Exp}$ & Obs & Exp & Obs & Exp \\
\hline Clethodim Alone & $96^{\mathrm{a}}$ & & $49^{\mathrm{a}}$ & & $63^{a}$ & & $93^{a}$ & & $50^{\mathrm{a}}$ & \\
\hline Dicamba or $2,4-\mathrm{D}$ & $0^{c}$ & & $0^{c}$ & & $0^{c}$ & & $0^{\mathrm{d}}$ & & $0^{c}$ & \\
\hline Separate Boom & $92^{\mathrm{a}}$ & 96 & $34^{\mathrm{a}}$ & 49 & $62^{a}$ & 63 & $89^{a}$ & 93 & $42^{\mathrm{a}}$ & 50 \\
\hline
\end{tabular}

Data were analyzed using Sidak's comparison method. LS-means with different letters within the same column shows significance. ${ }^{1}$ Herbicide rates are detailed in Section 2.2. ${ }^{2}$ "Obs" is an abbreviation of Observed control and 3 "Exp" is an abbreviation of Expected control using Colby's equation: $E=(X+Y)-(X Y) / 100$; any response of clethodim with dicamba or 2,4-D significantly less than clethodim alone is considered antagonistic.3.3. Glyphosate with Synthetic Auxins Field Trial.

Blackshaw et al. [30] found evidence of antagonism with clethodim and 2,4-D when looking at volunteer wheat (Triticum aestivum) control. Blackshaw et al. [30] found antagonistic responses of goosegrass four weeks after application when clethodim was applied with 2,4-D amine. Blackshaw et al. [30] found antagonism with clethodim and 2,4-D amine. Blackshaw et al. [30] conducted experiments looking at controlling volunteer wheat. The experiments were conducted in fields planted to wheat in the early 
spring to replicate volunteer wheat. Herbicide combinations that were used in this study were clethodim and quizalofop-P alone, mixtures with 2,4-D, mixtures with bromoxynil, mixtures with bromoxynil plus $\mathrm{MCPA}$, and mixtures of thifensulfuron plus tribenuron. To overcome the antagonism, he raised the rate of both herbicides. Data from all three site-years show clear agreement with the Blackshaw et al.'s [30] data, where clethodim was antagonized in the TMX and MIL methods.

The results of browntop millet control 7 DAA was $100 \%, 98 \%, 40 \%$, and $99 \%$ for the glyphosate alone, tank mix (TMX), mix-in-line (MIL), and separate boom (SPB) methods, respectively (Figure 4). Due to the TMX and SPB methods not being significantly lower than glyphosate alone, no antagonism was observed. The MIL application method resulted in lower browntop millet control, but it was due to improper mixing in the line. In all treatments with the MIL application, a block of dead browntop millet would be followed by a block of browntop millet that looked unaffected. The auxins in this trial had zero browntop millet control. It is believed that the control unit did not mix the herbicides properly. It appeared that the application across the plot switched back and forth between glyphosate and the synthetic auxin herbicide applied out of the boom then. The MIL method in Site-Year 1 at the R.R. Foil Plant Science Research Center was applied by using one manifold instead of two manifolds with a " $\mathrm{T}$ " in the line. It was because of the browntop millet control failure that the MIL method was modified to using two manifolds with a " $\mathrm{T}$ " in the line for the applications made in Site-Year 2 at the Black Belt Experiment Station and in Site-Year 3 at the R.R. Foil Plant Science Research Center in the summer of 2019.

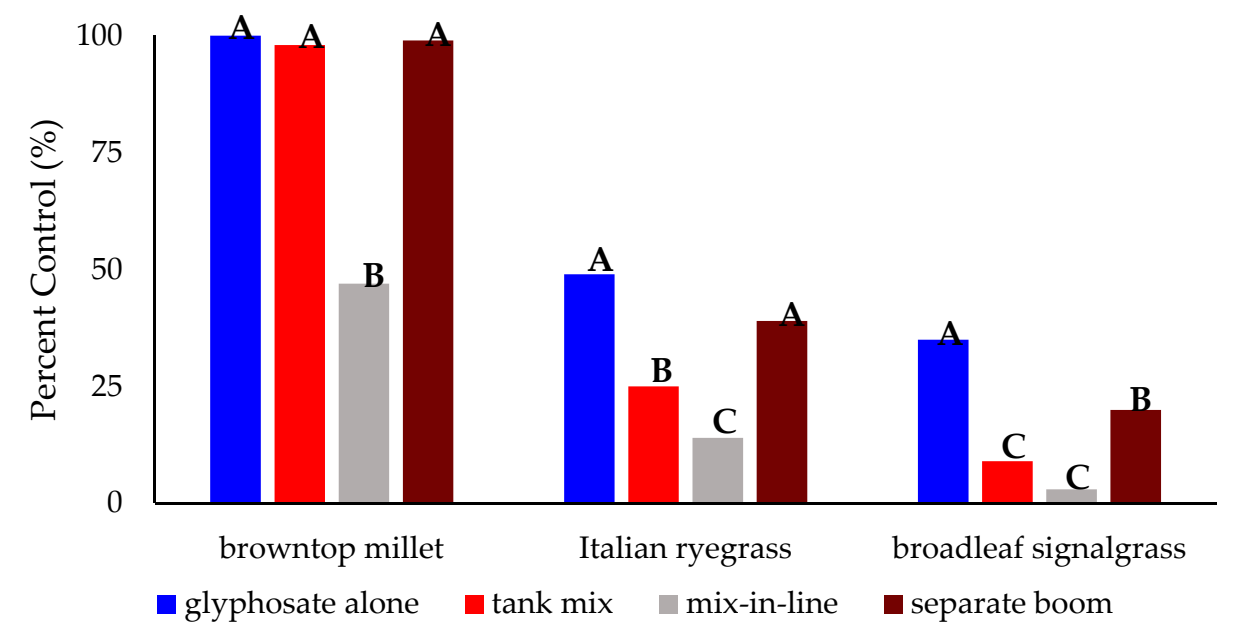

Figure 4. Comparison of application methods in control of browntop millet, Italian ryegrass, and broadleaf signalgrass seven days after application. Data were analyzed using Sidak's comparison method. LS-means with different letters within the same grass specie column indicate significance. Herbicide rates are detailed in Section 2.3.

For Italian ryegrass control 7 DAA, applying glyphosate with dicamba or 2,4-D through SPB was the only application method that resulted in weed control similar to glyphosate applied by itself (Figure 4). The SPB application method and glyphosate applied alone had $40 \%$ and $49 \%$ control, respectively (Figure 4). As shown in Figure 4, applying glyphosate with dicamba or 2,4-D through TMX or the MIL method resulted in weed control lower than the SPB application method. The TMX and MIL methods resulted in $26 \%$ and $14 \%$ control respectively, which was significantly lower than the $49 \%$ control from glyphosate applied alone. Broadleaf signalgrass control was at $35 \%$ when glyphosate was applied alone. Among the three application methods, applying glyphosate with dicamba or 2,4-D was greater-at 19\% control with the SPB application. The TMX method and the MIL method resulted in 10\% and 3\% control, respectively, which resulted in lower weed control than the SPB application method (Figure 4). All three application methods with glyphosate applied with dicamba or 2,4-D were 
still antagonistic due to all three methods having reduced control compared to glyphosate applied alone, as shown in Figure 4.

For Site-Year 1 at the R.R. Foil Plant Science Research Center, all treatments with dicamba and 2,4-D were applied at 281 and $533 \mathrm{~g}_{\text {ae ha }}{ }^{-1}$, respectively. For Site-Year 2 at the Black Belt Experiment Station and Site-Year 3 at the R.R. Foil Plant Science Research Center, the dicamba and 2,4-D applications were doubled to 562 and $1065 \mathrm{~g}_{\text {ae ha }}{ }^{-1}$, respectively. This was due to variability of results in Site-Year 1 . It was thought that, by increasing the rate of dicamba or 2,4-D, more antagonism may be observed based on the findings of Flint and Barrett [14]. Both dicamba and 2,4-D were applied at a half rate at Site-Year 1, and then increased to a full rate for Site-Years 2 and 3. Increased antagonism was seen due to increasing the rate of dicamba and 2,4-D. Increasing the rate of dicamba and 2,4-D also showed more antagonism with tank mix applications 7 DAA.

Glyphosate applied alone had 100\% control, which was the same control of browntop millet as glyphosate applied with dicamba or 2,4-D with the TMX and SPB application methods 28 DAA (Table 5). The MIL method had $84 \%$ control, which was the only method that resulted in less than $100 \%$ control of browntop millet 28 DAA (Table 5). Therefore, antagonism of browntop millet control was seen only with glyphosate applied with dicamba or 2,4-D with the MIL method. For control of Italian ryegrass at the Black Belt Experiment Station in Site-Year 2, the TMX application and the SPB application had $54 \%$ and $69 \%$ control, both statistically the same weed control at 28 DAA (Table 5). The MIL method had 50\% control of Italian ryegrass, which was lower than the SPB application method but not the TMX method, as shown in Table 5. Italian ryegrass control 28 DAA at the R.R. Foil Plant Science Research Center in Site-Year 3 was highest with glyphosate applied alone at 96\% and with glyphosate applied with dicamba or 2,4-D with the SPB application method at $92 \%$ (Table 5). Tank-mixing glyphosate with dicamba or 2,4-D resulted in $78 \%$ control, which was lower control of Italian ryegrass than applying the same herbicide combinations through separate booms, as shown in Table 5. The MIL application method had $48 \%$ less control of Italian ryegrass, which was lower than the TMX application method (Table 5).

Table 5. Comparison of application methods for control of browntop millet, Italian ryegrass, and broadleaf signalgrass with glyphosate and dicamba or 2,4-D 28 days after application.

\begin{tabular}{|c|c|c|c|c|c|c|c|c|}
\hline \multirow{3}{*}{ Application Method ${ }^{1}$} & \multirow{2}{*}{\multicolumn{2}{|c|}{$\begin{array}{l}\text { R.R. Foil Site-Year } 1 \\
\text { Browntop Millet }\end{array}$}} & \multirow{2}{*}{\multicolumn{2}{|c|}{$\begin{array}{c}\text { Black Belt Site-Year } 2 \\
\text { Italian Ryegrass }\end{array}$}} & \multicolumn{4}{|c|}{ R.R. Foil Site-Year 3} \\
\hline & & & & & \multicolumn{2}{|c|}{ Italian Ryegrass } & \multicolumn{2}{|c|}{ Broadleaf Signalgrass } \\
\hline & Obs $^{2}$ & $\operatorname{Exp}^{3}$ & Obs & Exp & Obs & $\operatorname{Exp}$ & Obs & Exp \\
\hline glyphosate alone & $100^{\mathrm{a}}$ & & $80^{\mathrm{a}}$ & & $96^{\mathrm{a}}$ & & $65^{\mathrm{a}}$ & \\
\hline dicamba or 2,4-D & $0^{c}$ & & $0^{\mathrm{c}}$ & & $0^{d}$ & & $0^{\mathrm{c}}$ & \\
\hline $\operatorname{tank} \operatorname{mix}$ & $100^{\mathrm{a}}$ & 100 & $54^{\mathrm{a}, \mathrm{b}}$ & 80 & $78^{b}$ & 96 & $39^{b}$ & 65 \\
\hline mix-in-line & $84^{b}$ & 100 & $50^{b}$ & 80 & $48^{c}$ & 96 & $18^{\mathrm{b}}$ & 65 \\
\hline separate boom & $100^{\mathrm{a}}$ & 100 & $69^{\mathrm{a}}$ & 80 & $92^{a}$ & 96 & $65^{\mathrm{a}}$ & 65 \\
\hline
\end{tabular}

Data were analyzed using Sidak's comparison method. LS-means with different letters within the same column indicate significance. ${ }^{1}$ Herbicide rates are detailed in Section 2.3. " ${ }^{2}$ "Obs" is an abbreviation of Observed control and $^{3}$ "Exp" is an abbreviation of Expected control using Colby's equation: $E=(X+Y)-(X Y) / 100$; any response of glyphosate with dicamba or 2,4-D significantly less than glyphosate alone is considered antagonistic.

The results of broadleaf signal grass control 28 DAA were similar to control of Italian ryegrass in Site-Year 3. Applying glyphosate with dicamba or 2,4-D through separate booms had statistically the same weed control as glyphosate applied alone (both 65\%, Table 5). Applications with the MIL and TMX methods had similar weed control of $18 \%$ and $39 \%$, respectively, of broadleaf signalgrass but both resulted in less control of $65 \%$ with the separate boom application method (Table 5).

Although no difference in the salt formulation was observed in the glyphosate and clethodim field studies, differences in 2,4-D formulations have been found in the literature. Amine formulations are less efficient in moving into the leaf compared to ester formulations [31]. Amine formulations are more water-soluble, thus requiring more time to penetrate through the waxy cuticle layer of the leaf. Clethodim may be interacting with the 2,4-D amine on the leaf. The amine formulation of 2,4-D 
could be coating the leaf and not allowing the clethodim to go through. Hard water can antagonize 2,4-D, by cations, such as $\mathrm{Ca}$ or $\mathrm{Mg}$, bonding to the negatively charged 2,4-D [32]. If cations bond to the 2,4-D, a large molecule may be sprayed on the plant. The large molecule is less efficient in penetrating through the leaf cuticle. Thelen et al. [33] used Nuclear Magnetic Resonance (NMR) technology to evaluate interactions of glyphosate with 2,4-D. They analyzed 2,4-D dimethylamine (amine formulation) and 2,4-D butoxyethylester (ester formulation) formulations. The use of 2,4-D dimethylamine mixed with glyphosate formed a dimethylamine salt of glyphosate while organic compounds of 2,4-D butoxyethylester reacted with glyphosate [33]. The cause of antagonism came from calcium cations from 2,4-D butoxyethylester interacted with the glyphosate molecule [33]. The chemical reactions of glyphosate and 2,4-D found by this study would classify under chemical antagonism, as defined by Green [8]. The antagonism of these 2,4-D formulations with glyphosate appears to be chemical reactions, which contradict Ou et al.'s [34] findings that supported dicamba antagonism with glyphosate occurring within the plant.

The results of the TMX application method resulting in antagonism in this trial is also supported by Flint and Barrett [14], where glyphosate activity on johnsongrass (Sorghum halepense) was reduced when dicamba or 2,4-D was applied in a tank-mixture with glyphosate. Translocation of glyphosate decreased when 2,4-D or dicamba was added, and less glyphosate was detected in the treated leaf [14]. Increasing the amount of glyphosate overcame the reduced translocation when mixed with dicamba or 2,4-D [14].

Ou et al. [34] looked at the combination of glyphosate and dicamba to control kochia. Their study applied two different rates of dicamba with glyphosate. The treatments were $560 \mathrm{~g}$ ae ha ${ }^{-1}$ (treatment (Trt) 1), a normal field rate, and $1400 \mathrm{~g}_{\text {ae ha}}{ }^{-1}$ (Trt 2), 2.5 times a normal field rate. The dicamba susceptible population had $47 \%$ control when combined with glyphosate at $350 \mathrm{~g}$ ae ha ${ }^{-1}$, half the recommended field rate. When $420 \mathrm{~g}$ ae ha ${ }^{-1}$ of glyphosate was applied with dicamba, there was only $50 \%$ control. Ou et al. [34] went on to state that glyphosate alone resulted in the best control of the dicamba susceptible kochia when compared to dicamba combinations with the same dose of glyphosate. When glyphosate was applied at $840 \mathrm{~g}_{\text {ae }} \mathrm{ha}^{-1}$, it had $95 \%$ control of dicamba susceptible kochia, and when dicamba was applied with glyphosate at 70, 140, 280, and $560 \mathrm{~g}$ ae ha ${ }^{-1}$, the control was $80 \%, 82 \%, 91 \%$, and $87 \%$ respectively [34]. This shows glyphosate being antagonized by dicamba.

The dicamba susceptible kochia absorbed more glyphosate when glyphosate was tank-mixed with dicamba than glyphosate applied alone $24 \mathrm{~h}$ after treatment [34]. When glyphosate was mixed with dicamba, less glyphosate translocated from the treated surface in the plant. Dicamba is an auxin herbicide; it can cause metabolic and physical reactions to the plant within hours of application. This means the growth of the plant can be inhibited. Glyphosate can transport down the phloem of plants [35]. Dicamba can weaken the phloem, meaning glyphosate may be restricted in its movement throughout the plant [34]. If glyphosate is restricted in its ability to be absorbed and translocated within the plant, then optimum control of the plant may not be reached. Glyphosate could also cause lower translocation of dicamba Glyphosate inhibits the EPSPS enzyme. This affects amino acid production in plants. When glyphosate kills the plant, the phloem ceases to operate in the plant $[36,37]$. Similar to glyphosate, dicamba also needs the phloem to move throughout the plant. If the phloem stops working, then dicamba is left idle. Results from Ou et al. [34] would support the theory that antagonism of dicamba and glyphosate can be classified as biochemical antagonism as defined by Green [8].

Antagonism of sethoxydim by bentazon was observed in Italian ryegrass control when the two herbicides were applied as a tank-mixture (TMX) or applied through the mix-in-line (MIL) methods. Applying sethoxydim with bentazon through separate booms (SPB) did overcome the antagonism in some cases. Applying clethodim with dicamba or 2,4-D through separate booms resulted in increased herbicide efficacy than the TMX and MIL application methods. Keeping clethodim separated from dicamba or 2,4-D by using separate booms for application may keep the two herbicides from chemically interacting. Delaying the herbicide interactions until they land on the plant's leaf surface may allow enough time for glyphosate to enter and kill the grass weeds as opposed to tank mixing 
them. More research is needed to investigate what chemical reactions, if any, are taking place when glyphosate is mixed with dicamba or 2,4-D. Applications with separate booms doubles the carrier volume from 140 to $280 \mathrm{~L} \mathrm{ha}^{-1}$. Instead of only one 02 flow-rate nozzle being used for the tank mix and mix-in-line application methods, a dual boom would have two sets of 02 flow-rate nozzles making applications, thus increasing the carrier volume. The rate of the herbicides did affect antagonistic responses. The fall 2018 trial at the R.R. Foil Plant Science Research Center had dicamba and 2,4-D applied at a half-rate while the trial at the Black Belt Experiment Station and the summer trial at R.R. Foil Plant Science Research Center applied dicamba and 2,4-D at a full rate. When clethodim was applied with dicamba and 2,4-D at a half rate, the TMX application method was not antagonistic according to the visual estimations of weed control 7, 21, and 28 DAA.

Overall, applying glyphosate with dicamba or 2,4-D yielded the highest control of weeds present when they were applied through separate booms. In most cases, making applications through separate booms did not show antagonism while antagonism was seen with the TMX and MIL application methods. Keeping glyphosate apart from dicamba or 2,4-D by using the SPB method to apply them may keep the two herbicides from interacting chemically, resulting in improved grass control. As stated in the paragraph above, delaying the herbicide interactions until they land on the plant's leaf may allow enough time for glyphosate to enter and kill the grass weed as opposed to tank mixing them; more investigation needs to be done to observe why.

Author Contributions: Conceptualization, J.C.F. and L.H.M.; methodology, J.C.F., D.B.R., and J.W.L.; software, L.H.M.; validation, L.H.M., J.C.F., A.E.B.-J., and D.B.R.; formal analysis, L.H.M.; investigation, L.H.M. and J.C.F.; resources, J.C.F., D.B.R., A.E.B.-J., and J.W.L.; data curation, L.H.M. and J.C.F.; writing-original draft preparation, L.H.M.; writing-review and editing, L.H.M., J.C.F., A.E.B.-J., D.B.R., and T.-M.T.; visualization, J.C.F. and L.H.M.; supervision, J.C.F., D.B.R., A.E.B.-J., and T.-M.T.; project administration, J.C.F.; and funding acquisition, J.C.F., A.E.B.-J., and D.B.R. All authors have read and agreed to the published version of the manuscript.

Funding: Funding was provided by Mississippi Agricultural and Forestry Experiment Station (MAFES) Specialty Research Initiative Grant and USDA Hatch Project Funds (MIS-522070).

Acknowledgments: This research could not have been done without the help of Kayla Broster, Justin Calhoun, Pedro Henrique Urach Ferreira, Michael Wesley, and Zachary Treadway.

Conflicts of Interest: The authors declare no conflict of interest.

\section{References}

1. Colby, S.R. Calculating synergistic and antagonistic responses of herbicide combinations. Weeds 1967, 15, 20-22. [CrossRef]

2. Flint, J.L.; Cornelius, P.L.; Barrett, M. Analyzing herbicide interactions: A statistical treatment of Colby's method. Weed Technol. 1988, 2, 304-309. [CrossRef]

3. Weed Science Society of America (WSSA). Available online: http://wssa.net/wssa/wssa-glossary/ (accessed on 24 July 2020).

4. Mueller, T.C.; Witt, W.W.; Barrett, M. Antagonism of johnsongrass (Sorghum halepense) control with fenoxaprop, haloxyfop, and sethoxydim by 2,4-D. Weed Technol. 1989, 3, 86-89. [CrossRef]

5. Zhang, J.; Hamill, A.S.; Weaver, S.E. Antagonism and synergism between herbicides: Trends from previous studies. Weed Technol. 1995, 9, 86-90. [CrossRef]

6. McMullan, P.M. Utility Adjuvants. Weed Technol. 2000, 14, 792-797. [CrossRef]

7. Penner, D. The impact of adjuvants on herbicide antagonism. Weed Technol. 1989, 3, 227-231. [CrossRef]

8. Green, J.M. Herbicide antagonism at the whole plant level. Weed Technol. 1989, 3, 217-226. [CrossRef]

9. Busi, R.; Goggin, D.E.; Heap, I.M.; Horak, M.J.; Jugulam, M.; Masters, R.A.; Napier, R.M.; Riar, D.S.; Satchivi, N.M.; Torra, J.; et al. Weed resistance to synthetic auxin herbicides. Pest Manag. Sci. 2018, 74, 2265-2276. [CrossRef]

10. Corteva Agriscience. Enlist Traits. Available online: https://www.enlist.com/en/traits.html (accessed on 10 January 2020). 
11. Zollinger, R.K. Grass antagonism with dicamba + clethodim. North Dakota State University. Available online: https://www.ag.ndsu.edu/cpr/weeds/grass-antagonism-with-dicamba-clethodim-07-06-17 (accessed on 10 January 2020).

12. Grichar, W.J.; Besler, B.A.; Brewer, K.D.; Baughman, T.A. Grass control in peanut (Arachis hypogaea) with clethodim and selected broadleaf herbicide combinations. Peanut Sci. 2002, 29, 85-88. [CrossRef]

13. Underwood, M.G.; Soltani, N.; Hooker, D.C.; Robinson, D.E. The addition of dicamba to POST applications of quizalofop-p-ethyl or clethodim antagonizes volunteer glyphosate-resistant corn control in dicamba-resistant soybean. Weed Technol. 2016, 30, 639-647. [CrossRef]

14. Flint, J.L.; Barrett, M.B. Antagonism of glyphosate toxicity to johnsongrass (Sorghum halepense) by 2,4-D and Dicamba. Weed Sci. 1989, 37, 700-705. [CrossRef]

15. Byrne, P.J.; Gempesaw, C.M.; Toensmeyer, U.C. An evaluation of Consumer Pesticide Residue Concerns and Risk Information Sources. J. Agric. Econ. 1991, 23, 167-174. [CrossRef]

16. Dunlap, R.E.; Beus, C.E. Understanding public concerns about pesticides: And empirical examination. J. Consum. Aff. 1992, 26, 418-438. [CrossRef]

17. Myers, J.P.; Antoniou, M.N.; Blumberg, B.; Carroll, L.; Colborn, T.; Everett, L.G.; Hansen, M.; Landrigan, B.P.; Lanphear, B.P.; Mesnage, R.; et al. Concerns over use of glyphosate-based herbicides and risks associated with exposures: A consensus statement. Environ. Health 2016, 15. [CrossRef] [PubMed]

18. Bridges, D.C.; Whitwell, T.; Walker, R.H. Johnsongrass control in soybeans with postemergence herbicides. In Proceedings of the Southern Weed Science Society 34 Annual Meeting, Dallas, TX, USA, 20-22 January 1981; Volume 34, p. 50.

19. Hartzler, R.G.; Foy, C.L. Compatibility of BAS 9052 OH with acifluorfen and bentazon. Weed Sci. 1983, 31, 597-599. [CrossRef]

20. Horng, L.C.; Ilnicki, R.D. Combinations of several grass and broadleaf herbicides for postemergence weed control in soybeans. In Proceedings of the Northeastern Weed Science Society, New York, NY, USA, 5-7 January 1982; Volume 36, p. 16.

21. Nalewaja, J.D.; Miller, S.D.; Dexter, A.G. Postemergence herbicide combinations for grass and broadleaf weed control. In Proceedings of the North Central Weed Control Conference, Omaha, NE, USA, 9-11 December 1980; Volume 35, p. 43.

22. Rhodes, G.N., Jr.; Coble, H.D. Influence of application variables on antagonism between sethoxydim and bentazon. Weed Sci. 1984, 32, 436-441. [CrossRef]

23. Rhodes, G.N., Jr.; Coble, H.D. Influence of bentazon on absorption and translocation of sethoxydim in goosegrass (Eleusine indica). Weed Sci. 1984, 32, 595-597. [CrossRef]

24. Lassiter, R.B.; Coble, H.D. Carrier volume effects on the antagonism of sethoxydim by bentazon. Weed Sci. 1987, 35, 541-546. [CrossRef]

25. Sperry, B.P. Optimizing Residual Herbicides in Mid-South Cropping Systems. Ph.D. Thesis, Mississippi State University, Starkville, MS, USA, 2019.

26. Sidak, Z. Rectangular confidence regions for the means of multivariate normal distributions. J. Am. Stat. Assoc. 1967, 62, 626-633. [CrossRef]

27. Minton, B.W.; Kurtz, M.E.; Shaw, D.R. Barnyardgrass (Echinochloa crus-galli) control with grass and broadleaf weed herbicide combinations. Weed Sci. 1989, 37, 223-227. [CrossRef]

28. Grichar, W.J. Sethoxydim and broadleaf herbicide interaction effects on annual grass control in penauts (Arachis hypogaea). Weed Technol. 1991, 5, 321-324. [CrossRef]

29. Wanamarta, G.; Penner, D.; Kels, J.J. The basis of bentazon antagonism on sethoxydim absorption and activity. Weed Sci. 1989, 37, 400-404. [CrossRef]

30. Blackshaw, R.E.; Harker, K.N.; Clayton, G.W.; O'Donovan, J.T. Broadleaf herbicide effects on clethodim and quizalofop-p efficacy on volunteer wheat (Triticum aestivum). Weed Technol. 2006, 20, 221-226. [CrossRef]

31. Nice, G.; Johnson, B.; Bauman, T. Amine or Ester, Which Is Better? Purdue University Extension, Weed Science: West Lafayette, IN, USA, 2004; Available online: https://www.panna.org/sites/default/files/2,4-D\%20Amine\% 20or\%20Ester\%202004-Purdue.pdf (accessed on 12 November 2019).

32. Schortgen, G.P. Enhancing Weed Control by Reducing Hard Water Antagonism of 2,4-D in Spray Tank Mixtures. Master's Thesis, Purdue University, West Lafayette, IN, USA, 2017.

33. Thelen, K.D.; Jackson, E.P.; Penner, D. 2,4-D interactions with glyphosate and sodium bicarbonate. Weed Technol. 1995, 9, 301-305. [CrossRef] 
34. Ou, J.; Thompson, C.R.; Stahlman, P.W.; Bloedow, N.; Jugulam, M. Reduced translocation of glyphosate and dicamba in combination contributes to poor control of Kochia scoparia: Evidence of herbicide antagonism. Sci. Rep. 2018, 8. [CrossRef]

35. Bromilow, R.H.; Chamberlain, K.; Tench, A.J.; Williams, R.H. Phloem translocation of strong acids-glyphosate, substituted phosphonic and sulfonic acids-in Ricinus communis L. Pest Manag. Sci. 1993, 37, 39-47. [CrossRef]

36. Amrhein, N.; Schab, J.; Steinrucken, H. The mode of action of the herbicide glyphosate. Naturwissenschaffen 1980, 67, 356-357. [CrossRef]

37. De Maria, N.; Becerril, J.M.; Garcia-Plazaola, H.A.; Felipe, M.; Fernandez-Pascual, M. New insights of glyphosate mode of action in nodular metabolism: Role of shikimate accumulation. J. Agric. Food Chem. 2006, 54, 2621-2628. [CrossRef]

(C) 2020 by the authors. Licensee MDPI, Basel, Switzerland. This article is an open access article distributed under the terms and conditions of the Creative Commons Attribution (CC BY) license (http://creativecommons.org/licenses/by/4.0/). 